\title{
Physical and physiological quality of rice seeds in function of drying temperature and storage ${ }^{1}$
}

\author{
Maurício Albertoni Scariot ${ }^{2 *} \mathbb{D}$, Gustavo Campos Soares ${ }^{3}$, Lauri Lourenço Radünz ${ }^{2}$, Rafael Gomes Dionello ${ }^{2}$
}

10.1590/0034-737X202168010004

\begin{abstract}
The objective with the work was to evaluate, during storage, the rice seeds physical and physiological quality, cultivar IRGA 424 RI, dried with different drying air temperatures. For such, rice seeds were harvested with a moisture content of $22 \%$. Then, they were subjected to drying in a cross-flow dryer, operating in an intermittent system and using the 55 and $65^{\circ} \mathrm{C}$ drying air temperatures. After, samples containing $50 \mathrm{~kg}$ of seeds were stored in PP Woven Bags for 240 days. After drying and every 60 days, physical and physiological analyses were performed. The experiment was conducted under a completely randomized design, arranged in a split-plot scheme, with 4 replications. The physical quality, estimated by the seed hectoliter weight, decreased during storage, regardless of the drying air temperature. The germination percentage, as well as the vigor increased during storage, regardless of drying air temperature due to the dormancy overcoming process. The dry seeds with the highest drying air temperature showed less vigor throughout the storage, according to the cold test. The rice seeds drying with an air temperature of $65^{\circ} \mathrm{C}$, promoted a higher drying speed and did not negatively influence the seeds physical and physiological quality, however, reduced the vigor.
\end{abstract}

Keywords: Oryza sativa L.; conservation; thermal damage; germination; vigor.

\section{INTRODUCTION}

Rice (Oryza sativa L.) is a crop produced and consumed in several countries. In world, rice production in 2018 was 782.0 million tons (Fao, 2020). Brazilian rice production, for the 2020/21 harvest, is estimated at 10.9 million tons with an average productivity of $6,374 \mathrm{~kg} \mathrm{ha}^{-1}$ (Conab, 2020).

The use of rice seeds with better quality promotes larger plant stand and better initial development in the field, providing greater seed productivity (Souza et al., 2007). Seed quality comprises genetic, sanitary, physical and physiological characteristics, which determine its performance in the field, as well as the conservation potential during storage (Rodo et al., 2000).

Drying and storage comprise some of the main processes in the rice seeds production since they provide their conservation until sowing in the next crop. However, when poorly handled, these processes can significantly alter the seed quantitative and qualitative characteristics (Marques et al., 2014a; Scariot et al., 2018).

Artificial drying is an indispensable process for reducing the rice seeds moisture content after harvest, enabling storage, since it is not recommended to harvest seeds with low moisture content, due to the greater susceptibility to breakage and cracks and loss of quality due to staying in the field. However, during drying the seeds can change the chemical composition and physical and physiological characteristics, depending on the conditions in which it is carried out, the most important factor being the temperature of the drying air used (Garcia et al., 2004; Menezes et al., 2012).

In storage, the most important factors for maintaining seed quality are the moisture content and the temperature

\footnotetext{
Submitted on April 15 $5^{\text {th }}, 2020$ and accepted on October $18^{\text {th }}, 2020$.

'This work is part of the doctoral thesis of the first author.

${ }^{2}$ Universidade Federal do Rio Grande do Sul, Faculdade de Agronomia, Departamento de Fitossanidade, Porto Alegre, Rio Grande do Sul, Brazil. mauricioalbertoniscariot@gmail.com; laurilr@gmail.com; rafdionello@hotmail.com

${ }^{3}$ Instituto Rio-Grandense do Arroz (IRGA), Cachoeirinha, Rio Grande do Sul, Brazil. gustavocampossoares@gmail.com

*Corresponding author: mauricioalbertoniscariot@gmail.com.
} 
and relative humidity of the air, since these are the main responsible for breathing and, consequently, for deterioration. Also, during storage, seeds undergo the action of numerous processes that favor deterioration, such as reserves reduction, enzymatic changes, damage to membranes and toxic substances accumulation resulting from the oxidation of fatty acids, such as aldehydes and phenolic compounds, beyond to the insect and fungi attack (Park et al., 2012).

Seed's preservation capacity during storage is related to its initial quality and the drying conditions and storage (Deliberali et al., 2010). Therefore, the use of high temperatures can cause immediate damage to the seeds, found right after drying, and latent damage, observed over time by reducing the seed storage potential (Afonso Júnior \& Corrêa, 2000).

Given the above, the objective with the work was to evaluate, after drying and during storage, the rice seeds physical and physiological quality, cultivate IRGA 424 RI, dried with different drying air temperatures.

\section{MATERIAL AND METHODS}

The study was carried out in the 2017/18 crop at the Rio Grandense rice Institute (IRGA), located in the municipality of Cachoeirinha/RS, the Experimental Agronomic Station of the Federal University of Rio Grande do Sul (EAS / UFRGS), located in the municipality of Eldorado do Sul / RS and at the Grain Post-Harvest Laboratory at the Federal University of Rio Grande do Sul Faculty of Agronomy, located in Porto Alegre/RS.

The experiment was conducted completely randomized design, in a a split-plot scheme, with 4 replications. The plots were composed by the storage time $(0,60,120,180$ and 240 days) and the subplots by the drying air temperature (55 and $65^{\circ} \mathrm{C}$ ).

The cultivation to obtain rice seeds, cultivar IRGA 424 RI, was carried out at IRGA, according to the technical indications of the culture (Sosbai, 2016). When the seeds reached a moisture content of $22 \%$ on a wet basis (w.b.) mechanized harvesting was performed, with the aid of a self-propelled harvester. After the harvest the pre-cleaning process was carried, in an air machine and sieves, aiming at reducing the percentage of impurities to $1 \%$.

The seeds were dried at EEA / UFRGS in a cross-flow dryer with static capacity for $1 \mathrm{~m}^{3}$ of seeds, operating in an intermittent system with a 1:1 ratio (drying time and equalization time). Drying was carried using two different drying air temperatures, 55 and $65^{\circ} \mathrm{C}$, until the seeds reached a moisture content of approximately $12 \%$ w.b.

During the drying, seed samples were taken every 30 minutes, through a trapdoor in the dryer's discharge duct, to monitor the moisture content and the temperature of seeds. Moisture content was determined with the aid of a portable meter from the brand Gehaka ${ }^{\circledR}$ and model G650, with subsequent confirmation by the oven method at 105 $\pm 3^{\circ} \mathrm{C}$ for $24 \mathrm{~h}$ (Brazil, 2009). To determine the temperature, the seeds were placed in a styrofoam container for 2 minutes. Afterwards, the temperature was measured with the aid of a mercury thermometer.

After drying, samples containing $50 \mathrm{~kg}$ of rice seeds were stored in PP Woven Bags for 240 days. During the storage, which occurred between the months of April and December 2018, the temperature and relative humidity of the place were monitored with the aid of a digital thermohygrometer. The means temperature and relative humidity recorded during storage were $18.6^{\circ} \mathrm{C}$ and $80.1 \%$, respectively (Figure 1).

Every 60 days, during storage, physical analyzes were carried, consisting of the determination of moisture content, weight 1000-seeds, hectoliter weight, and physiological analyzes, consisting of germination test, first germination count, germination speed index, cold test, electrical conductivity, shoot length and dry-matter transfer.

The moisture content was determined in triplicate by repetition for each treatment, using oven method at $105 \pm$ $3^{\circ} \mathrm{C}$ for $24 \mathrm{~h}$ (Brazil, 2009).

The thousand seed weight was determined by counting eight repetitions of 100 seeds per treatment. Determination result was obtained by multiplying the average weight obtained at the eight repetitions by ten and expressed in grams (g) (Brazil, 2009).

The hectoliter weight was determined on a hectoliter weighing-machine, with capacity of a quarter of liter. Test was performed in triplicate by repetition for each treatment. The result being determined from average of values obtained and expressed in $\mathrm{kg} \mathrm{hL}^{-1}$ (Brazil, 2009).

The germination test was conducted with 400 seeds per treatment, which were sown in rolls of germitest paper soaked in distilled water at a proportion of 2.5 times their weight and kept in a germinator at $25 \pm 3^{\circ} \mathrm{C}$ and photoperiod of $12 \mathrm{~h}$. Evaluations were carried out in accordance with Rules for Seed Analysis and the results expressed in percentage (Brazil, 2009).

The first germination count was performed together with the germination test. These assessments occurred at 5 days after sowing, by counting the number of normal seedlings. Results was expressed in percentage (Brazil, 2009).

The germination speed index followed the same methodology described for the germination test to perform sowing. However, only 20 seeds were placed in the upper third of each roll, for a total of eight rolls for each treatment. Over the course of seven days, the number of germinated seeds that gave rise to normal seedlings each day was counted. The index was calculated as described by Maguire (1962). 
The cold test was conducted on germitest paper rolls, using the same methodology described for the germination test. However, immediately after sowing, the rolls were packed in plastic bags and placed at a temperature of $10^{\circ} \mathrm{C}$ for seven days in a BOD chamber, according to Loeffler $e t$ al. (1985). Afterwards, the rolls were transferred to a germinator at a temperature of $25^{\circ} \mathrm{C}$, for seven days. Then, normal seedlings were counted, with the results expressed in percentage.

The seed electrical conductivity was carried out by the massal system, in which 50 seeds were weighed by repetition of each treatment, which were later placed in containers and immersed in $50 \mathrm{~mL}$ of distilled water. The containers were kept in BOD chambers at $25^{\circ} \mathrm{C}$ for 24 hours. The evaluations were performed with the aid of a bench conductivimeter (Gehaka ${ }^{\circledR}$, model CG-220), and the values expressed in $\mu \mathrm{s} \mathrm{cm}^{-1} \mathrm{~g}^{-1}$ (Marcos Filho et al., 1987).

The shoot length was obtained along with the germination speed index, through measurement, with the aid of a ruler graduated in millimeters, of the aerial part of 10 seedlings, obtained at random, on the 14th day after sowing (Kappes et al., 2012). The dry matter transfer was performed together with the determination of the shoot length. After measuring the aerial part of the seedlings, the endosperm of normal seedlings was excised, which were subsequently dried in an oven at a temperature of $65^{\circ} \mathrm{C}$ until constant weight, the results being expressed in grams per seedling.

The data were submitted to analysis of variance by the F Test $(p \leq 0.05)$ with the aid of the $R \AA$ software. The storage time was submitted to regression analysis using the SigmaPlot ${ }^{\circledR} 14.0$ software. The drying temperatures were analyzed by the Tukey Test $(\mathrm{p} \leq 0.05)$ with the aid of the $\mathrm{R} \circledast$ software.

\section{RESULTS AND DISCUSSION}

After drying, the rice seeds, from different temperature conditions, had moisture content between 12.2 and $12.3 \%$. The drying temperature directly affected the drying time, with shortest drying time $(5.5 \mathrm{~h})$ being observed for the temperature of $65^{\circ} \mathrm{C}$ and the longest time $(6.5 \mathrm{~h})$ for the temperature of $55^{\circ} \mathrm{C}$.

The average seed mass temperatures for conditions of 55 and $65{ }^{\circ} \mathrm{C}$ were 34.9 and $37.7{ }^{\circ} \mathrm{C}$, respectively. The maximum reached in each drying temperature were $38^{\circ} \mathrm{C}$ and $43^{\circ} \mathrm{C}$ for 55 and $65^{\circ} \mathrm{C}$, respectively.

According to variance analysis (F Test $(\mathrm{p} \leq 0.05))$, there was only significant effect of storage time for the variables moisture content and hectoliter weight (Table 1). As for the thousand seed weight, there was no significant effect of the factors studied, presenting an average of $25.0 \mathrm{~g}$.

Rice seeds moisture content, due to the tendency to hygroscopic balance with air, showed a higher value around 120 days of storage, with lower and similar values in the other analyzed times (Figure 2A).

Table 1: Variance analysis summary for moisture content (MC), thousand seed weight (TSW) and hectoliter weight (HW) of rice grains as a function of drying air temperature and storage time

\begin{tabular}{lcccc}
\hline \multirow{2}{*}{ SV } & \multirow{2}{*}{ DF } & \multicolumn{3}{c}{$\boldsymbol{p}$ value } \\
\cline { 3 - 5 } & & MC & TSW & HW \\
\hline ST & 4 & $<0.0001$ & 0.0929 & $<0.0001$ \\
DT & 1 & 0.4284 & 0.6009 & 0.6008 \\
DT x ST & 4 & 0.9710 & 0.8616 & 0.8392 \\
\hline CV $(\%)$ & & 1.65 & 1.88 & 0.25
\end{tabular}

SV: sources of variation; DF: degrees of freedom; ST: storage time; DT: temperature. CV: coefficient of variation.

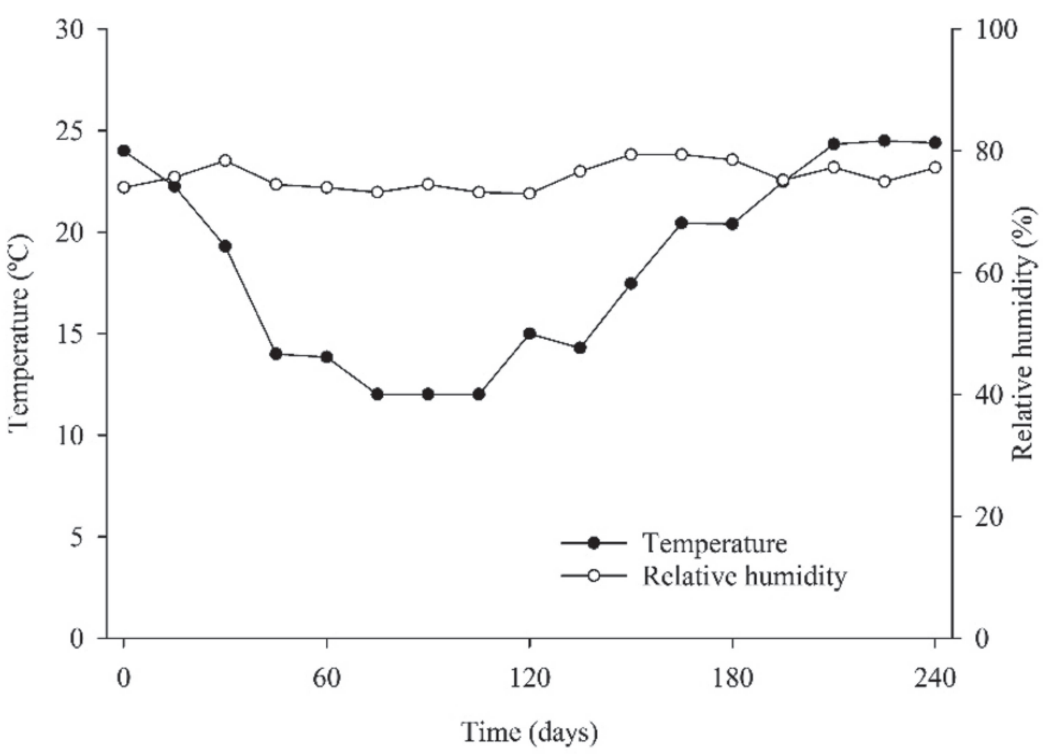

Figure 1: Biweekly mean of temperature and relative humidity in storage site the of rice seeds, IRGA 424 RI cultivar. 
The observed increase in seeds moisture content after 120 days of storage may be related to occurrence of winter period, in which the temperature is lower and, in this condition, the hygroscopic balance of the seeds with the air occurs in moisture contents higher, since it the relative humidity of the air did not show significant oscillations over time (Figure 1 ) (Choi et al., 2010). This variation in seeds moisture content was also observed by other authors (Ferrari Filho et al., 2014; Tiecker Junior et al., 2014; Lima et al., 2016).

Seeds hectoliter weight reduced linearly during storage, regardless of drying air temperature (Figure 2B). Similar results were found by Morás et al. (2006) and Scariot et al. (2018) in which they verified a reduction in the hectoliter weight of rice and wheat seeds over 360 and 240 days of storage under environmental conditions, respectively.

However, the seeds hectoliter weight decreased $1.2 \%$ at the end of the experiment, a value considered low. Therefore, this variation along storage could only be verified due to the high precision of experiment, in view of the low coefficient of variation $(0.25 \%)$ obtained for this variable.

The reduction seeds density, observed by decrease of hectoliter weight, may be due to the consumption of dry matter due to the respiratory process (Atungulu et al., 2017). Another factor that can reduce the hectoliter weight is the attack of insects and fungi (Antunes et al., 2011), however in this period the presence of storage insects and fungi in the rice grains was not observed.

Thousand seed weight did not show statistically significant changes during storage, regardless of the drying air temperature used. Similar results were found by Lima et al. (2019), who found that the thousand seed weight of rice, cultivar Jaçanã, did not vary until 120 days of storage.

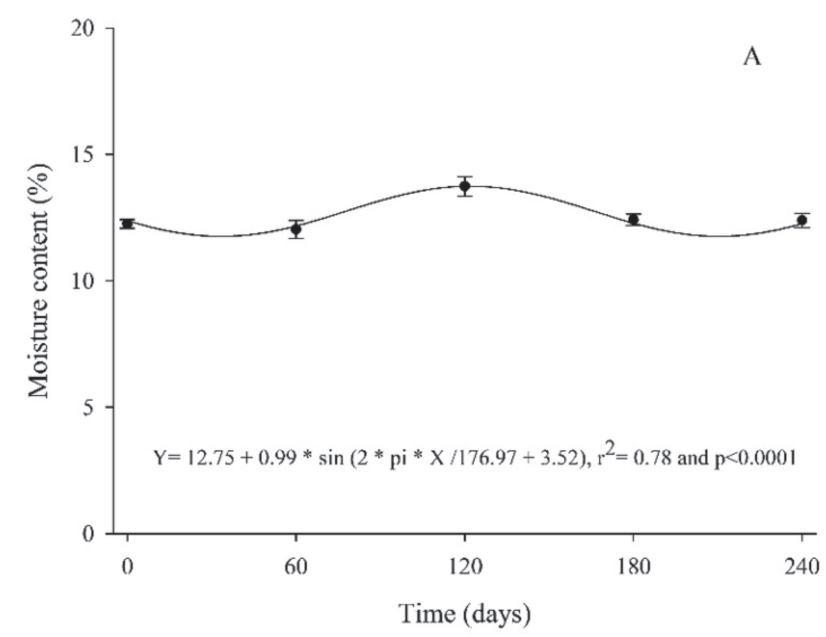

The results for thousand seeds weight and the low reduction of seeds hectoliter weight along time may be related to storage temperature, which can be considered adequate for maintaining the rice seeds physical quality according to Ying et al. (1998), since it presented an average of $18.6^{\circ} \mathrm{C}$.

According to the variance analysis ( $F$ test $(\mathrm{p} \leq 0.05)$ ), there was a significant effect of storage time for the variables germination, first germination count and germination speed index of the rice seeds (Table 2). For the variables cold test and electrical conductivity, an effect of interaction between storage time and drying temperatures was verified. As for the variables dry matter transfer and shoot length, no significant effect of factors tested was observed, with general averages of $6.5 \mathrm{~g}$ seedling $^{-1}$ and 6.4 $\mathrm{cm}$ being obtained, respectively.

Rice seeds germination increased linearly during storage, regardless of drying air temperature (Figure 3A). This result agrees with those obtained by Vieira et al. (2002), Marques et al. (2014) and Lima et al. (2019), which verified an increase in rice seeds germination up to 270 , 240 and 120 days of storage, respectively.

Germination speed index and first germination count values of rice seeds(Figures $3 \mathrm{~B}$ and C) increased linearly during storage, regardless of drying air temperature, as verified for the germination test (Figure 3A). These results are in agreement with those obtained by Lima et al. (2019), which verified an increase in the first germination count values of rice seeds up to 120 days of storage. Vieira et al. (2002) observed an increase in the rice seeds germination speed up to approximately 180 days of storage.

Seeds electrical conductivity increased during storage for both drying air temperatures, but with a more prominent increase in seeds subjected to higher temperatures (Figure 4A). These results are in agreement with those found by Wang et al. (2017), where they found that drying air

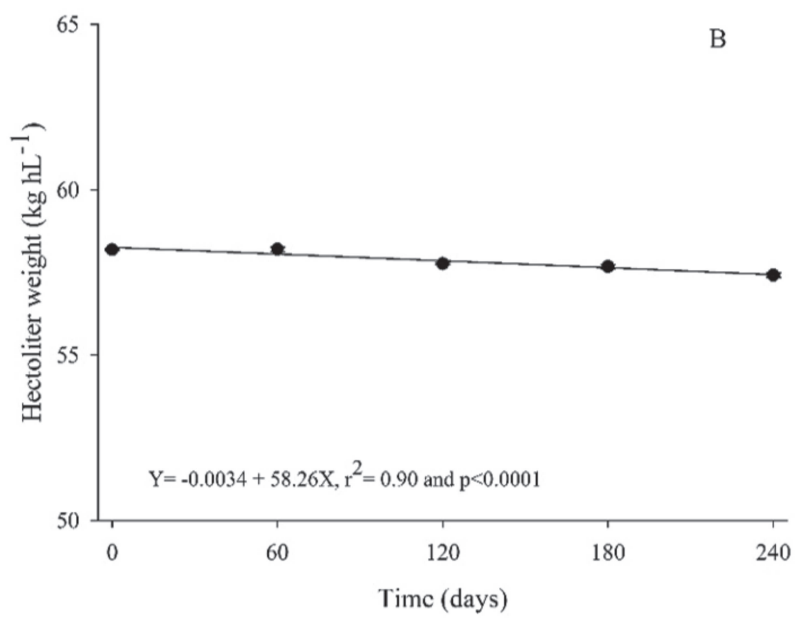

Figure 2: Moisture content (A) and hectoliter weight (B) of rice seeds, cultivar IRGA 424 RI, during conventional storage under environmental conditions for 240 days.

Rev. Ceres, Viçosa, v. 68, n.1, p. 031-038, jan/feb, 2021 
temperatures above $60{ }^{\circ} \mathrm{C}$ caused an increase in the electrical conductivity of rice seeds. Marques et al. (2014a) and Lima et al. (2019) found an increase in the electrical conductivity values of rice seeds during storage for 360 and 120 days, respectively.

The highest electrical conductivity values, observed for dry seeds at the highest temperature $\left(65^{\circ} \mathrm{C}\right)$, are due to the damage caused by the use of high drying air temperatures, which reflect primarily on damage to seeds cell membranes, changing their permeability and causing greater solute leaching (Garcia, 2004).
The increase in the electrical conductivity values during storage evidence the progress of rice seeds deterioration process over time, since the determination of electrical conductivity is based on the principle that more deteriorated seeds have less capacity to repair cell membranes during the water absorption process and, in consequence, greater solute leaching occurs, culminating in the increase in electrical conductivity values (Marcos Filho, 2015).

According to the cold test, there was an increase in seed vigor during storage, for both drying air temperatures,

Table 2: Variance analysis summary of germination (G), first germination count (FGC), germination speed index (GSI), cold test (CT), electrical conductivity (EC), shoot length (LS) and seedlings dry matter (DM) of rice grains as a function of drying air temperature and storage time

\begin{tabular}{lcccccccc}
\hline \multirow{2}{*}{ SV } & DF & \multicolumn{9}{c}{$\boldsymbol{p}$ value } \\
\cline { 2 - 9 } & & G & FGC & GSI & CT & EC & LS & DM \\
\hline TI & 4 & $<0.0001$ & $<0.0001$ & $<0.0001$ & $<0.0001$ & $<0.0001$ & 0.2911 & 0.1122 \\
TE & 1 & 0.3717 & 0.7604 & 0.6726 & $<0.0001$ & $<0.0001$ & 0.2278 & 0.9263 \\
TI x TE & 4 & 0.8377 & 0.2703 & 0.3053 & $<0.0001$ & 0.0120 & 0.8976 & 0.1267 \\
\hline CV $(\%)$ & & 1.81 & 11.56 & 6.83 & 3.34 & 3.33 & 6.9 & 3.78 \\
\hline
\end{tabular}

SV: sources of variation; DF: degrees of freedom; ST: storage time; DT: temperature. CV: coefficient of variation
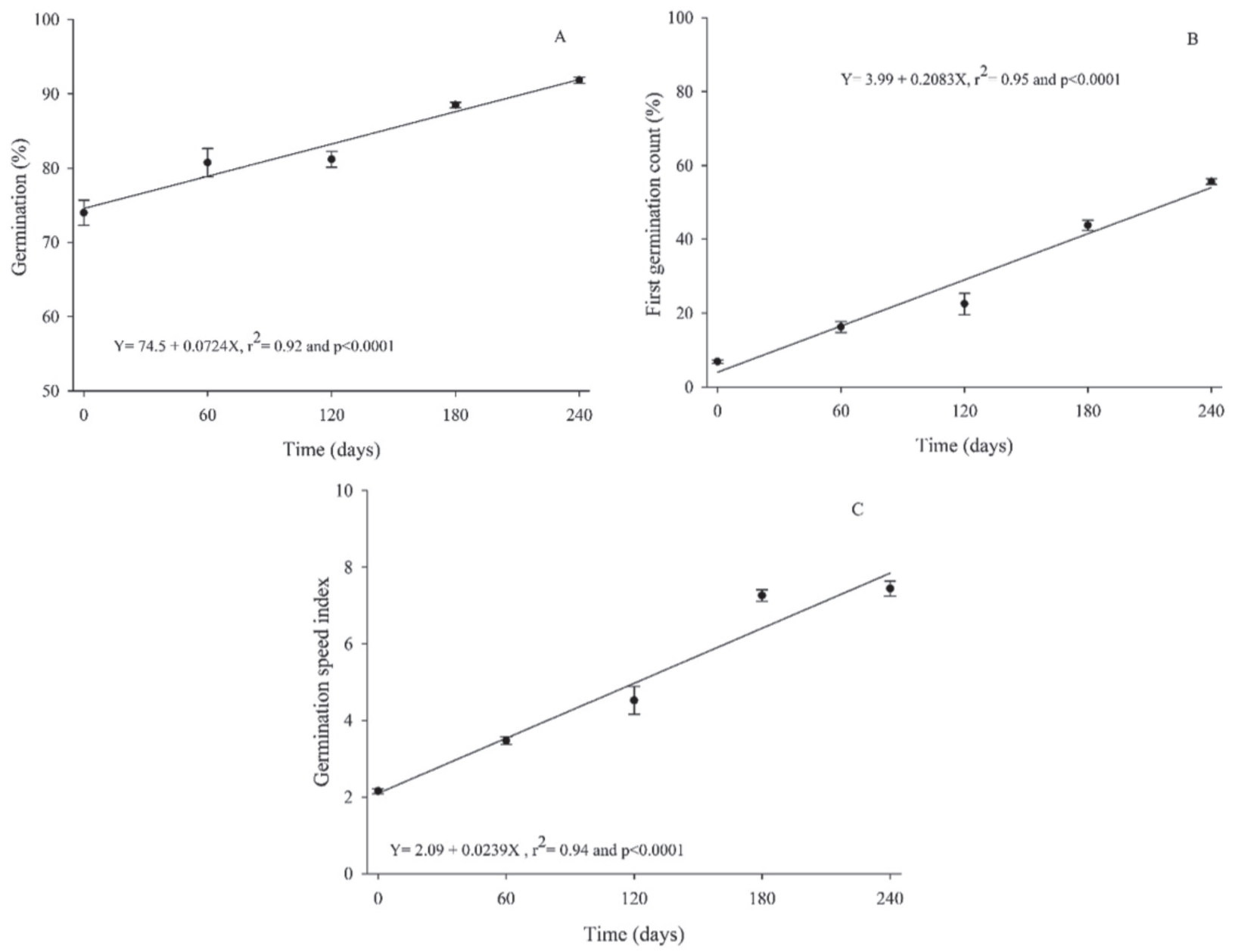

Figure 3: Germination (A), first germination count (B) and germination speed index (C) of rice seeds, cultivar IRGA 424 RI, during conventional storage under environmental conditions for 240 days. 
due to the dormancy overcoming process. Right after drying and throughout the storage period, dry seeds with the highest drying air temperature $\left(65^{\circ} \mathrm{C}\right)$ exhibited lower germination percentages, when compared to dry seeds with the lowest drying air temperature $\left(55^{\circ} \mathrm{C}\right)($ Figure $4 \mathrm{~B})$. These results are in agreement with those obtained by Saravia et $a l$. (2007), who verified, through the cold test, that dry rice seeds with a temperature of $60^{\circ} \mathrm{C}$ showed less vigor soon after drying and over 180 days of storage, when compared with dry seeds with the temperature of $40^{\circ} \mathrm{C}$.

The results obtained by cold test allow inferring that the higher temperature caused immediate and latent damages on the rice seeds vigor, since the dried seeds with the highest temperature presented less vigor soon after drying and along the whole experiment, when comparing the dry seeds with the lowest temperature. According to Garcia et al. (2004), the thermal damages caused in seeds due to the drying temperature elevation are reflected in the physiological system, such as, for example, in subcellular changes, reserves denaturation, damages to the embryonic axis and the cell membranes.

According to the results obtained, it is suggested that the total dormancy overcoming of rice seeds did not occur during the experiment execution, since the germination percentage, germination speed, first count values and the vigor, measured by cold test, showed an increase until the last evaluation period.

Overcoming dormancy of rice seeds may be related to enzymatic processes, inhibiting compounds of germinative process, storage temperature, genetic aspects of each cultivar and environmental conditions during grain maturation in the field (Vieira et al., 2008). As with other cereals, dormancy is overcome during storage and, thus, seed germination may increase over time.

According to Vieira et al. (2008), the rise in temperature during storage promotes the dormancy overcoming of rice seeds in a faster way, while lower temperatures cause the maintenance of dormancy for a longer time. Therefore, the storage temperature may have influenced the time for overcoming seed dormancy in the present study, since the temperature during storage remained, for the most part, below $20^{\circ} \mathrm{C}$ and presenting an average of $18,6 \%$. These temperature values can be considered low according to Marques et al. (2014b), who found that rice seeds stored at temperatures up to $18{ }^{\circ} \mathrm{C}$ showed an increase in the germination percentage up to 7 months of storage, while seeds stored under environmental conditions, with an average temperature of $25^{\circ} \mathrm{C}$, showed the highest percentages of germination at 3.5 months of storage.

The results obtained in tests based on seedling growth showed that they were not sensitive enough to estimate seed vigor as a function of drying air temperature and storage time, except for the tests of first germination count and germination speed index, which provided seed vigor estimates during storage.

In contrast, the cold and electrical conductivity tests showed sufficient sensitivity to measure the vigor of the seeds due to the increase in the drying air temperature and storage time. This result shows that the primary damage caused by high drying air temperatures occurs on the seeds cell membranes, since their integrity can directly influence the results of these tests.

According to Marcos Filho et al. (2015), the electrical conductivity test is based on the theory that deteriorated seeds have less capacity to restructure the cell membrane during the imbibition process, culminating in a greater amount of leachate. One of the stresses suffered by seeds during the cold test execution is the increase in the extravasation of cellular solutes during the water absorption process, which is favored by low temperature since this slows down the process of reorganization and repair of cell membranes.
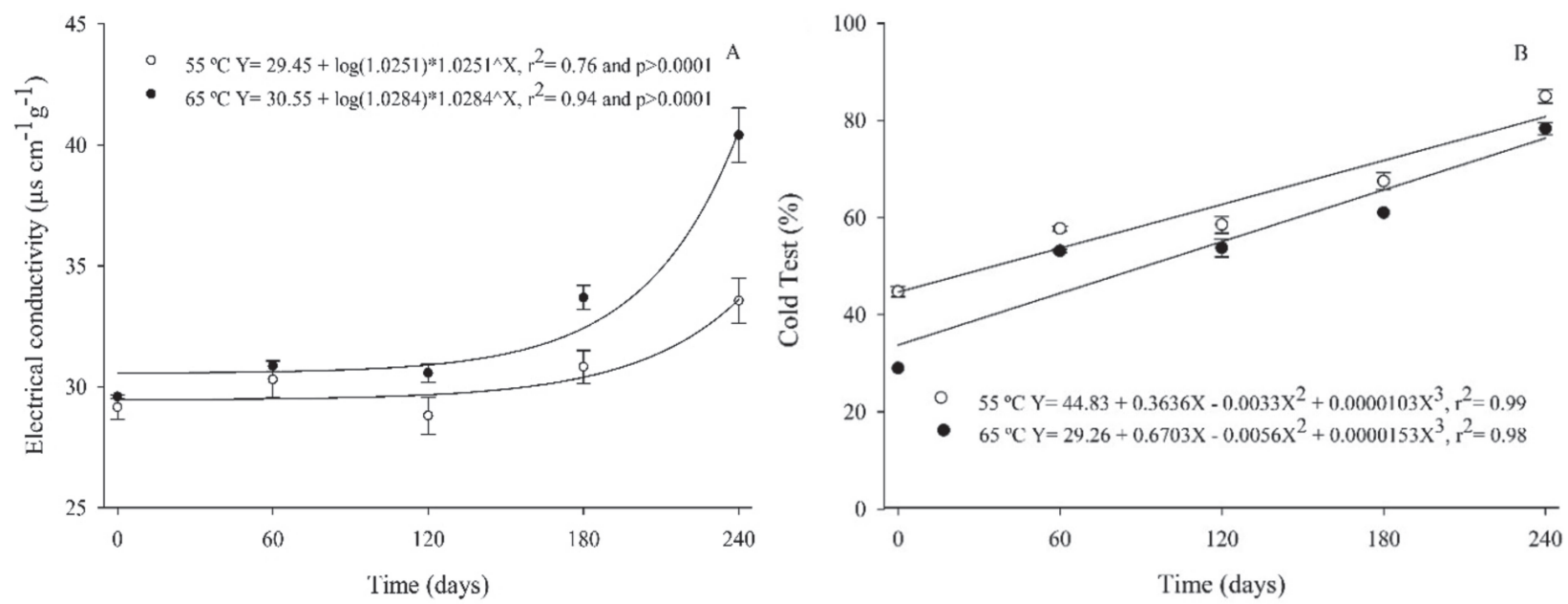

Figure 4: Electrical conductivity (A) and germination, through the cold test, of rice seeds, cultivar IRGA 424 RI, dried at different drying air temperatures and stored in environmental conditions for 240 days.

Rev. Ceres, Viçosa, v. 68, n.1, p. 031-038, jan/feb, 2021 


\section{CONCLUSIONS}

Hectoliter weight of rice seeds, cultivar IRGA 424 RI, decreased over 240 days of storage under environmental conditions, while the thousand seeds weight did not vary.

Germination and vigor percentage of rice seeds, cultivar IRGA 424 RI, increased over 240 days of storage due to the dormancy overcoming process.

Rice seeds dormancy, cultivar IRGA424 RI, is influenced by storage conditions, mainly by air temperature, it is not possible to observe the total overcoming up to 240 days of storage under the conditions in which the experiment was conducted.

Rice seeds drying, cultivar IRGA 424 RI, with drying air temperature of $65^{\circ} \mathrm{C}$, promoted a higher drying speed and did not negatively influence the seeds physical and physiological quality, however, they promoted a reduction of vigor (cold test) and an increase in electrical conductivity.

\section{ACKNOWLEDGEMENTS, FINANCIAL SUPPORT AND FULL DISCLOSURE}

The authors would like to thank the Insituto Rio Grandense do Arroz (IRGA) for support for the development of this research and the Coordenação de Aperfeiçoamento de Pessoal de Nível Superior (CAPES) for the Phd scholarship granted to the first author. The authors have declared not any conflict of interests.

\section{REFERENCES}

Afonso Júnior PC \& Corrêa PC (2000) Efeitos imediato e latente da secagem de sementes de feijão colhidas com diferentes níveis de umidade. Ciência e Agrotecnologia, 24:33-40.

Antunes LEG, Viebrantz PC, Gottardi R \& Dionello RG (2011) Características físico-químicas de sementes de milho atacados por Sitophilus zeamais durante o armazenamento. Revista Brasileira de Engenharia Agrícola e Ambiental, 15:615-620.

Atungulu GG, Thote S \& Wilson S (2017) Dry matter loss for hybrid rough rice stored under reduced-oxygen conditions. Cereal Chemistry, 94:497-501

Brasil (2009) Regras para análise de sementes. Brasília, Mapa/ ACS. 399p

Choi BM, Lanning SB \& Siebenmorgen TJ (2010) A review of hygroscopic equilibrium studies applied to rice. Transactions of the ASABE, 53:1859-1872.

Conab - Companhia Nacional De Abastecimento (2020) Acompanhamento da safra brasileira de grãos, v. 8 - Safra 2020/21, n. 5: segundo levantamento. Brasília, CONAB. 184p.

Deliberali J, Oliveira M, Durigon A, Dias ARG, Gutkoski LC \& Elias MC (2010) Efeitos de processo de secagem e tempo de armazenamento na qualidade tecnológica de trigo. Ciência e Agrotecnologia, 34:1285-1292.

Fao - Organização das Nações Unidas para a Alimentação e a Agricultura (2020). Available at: http://www.fao.org/faostat/en/ \#home. Accessed on: December $11^{\text {th }}, 2020$.
Ferrari Filho E, Antunes LEG, Tiecker A, Lima RF \& Dionello RG (2014) Efeito de diferentes fontes energéticas na secagem e de tempos de armazenagem sobre as características físicas e tecnológicas de sementes de milho. Pesquisa Agropecuária Gaúcha, 20:71-79.

Garcia DC, Barros ACSA, Peske ST \& Menezes NL (2004) A secagem de sementes. Ciência Rural, 34:603-608.

Kappes C, Arf O, Ferreira JP, Portugal JR, Alcalde AM, Arf MV \& Vilela RG (2012) Qualidade fisiológica de sementes e crescimento de plântulas de feijoeiro, em função de aplicações de paraquat em pré-colheita. Pesquisa Agropecuária Tropical, 42:9-18.

Lima JME, Smiderle OJ, Galvão LM, Sá AR \& Cordeiro AC (2019) Relation of milling process and physiological quality of rice seeds during storage. Revista de Ciências Agrárias, 42:30-39.

Lima RF, Tiecker A, Rizzoto PRJ, Dionello RG \& Radunz LL (2016) Qualidade de sementes de milho submetidos à secagem com lenha e posteriormente armazenados em ambiente natural. Revista Brasileira de Milho e Sorgo, 15:594-606.

Loeffler TM, Meyer JL \& Burris JS (1985) Comparação dos dois processos de ensaio para utilização em estudos de secagem do milho. Ciência e Tecnologia de Sementes, 13:653-658.

Maguire JD (1962) Velocidade de germinação na seleção e avaliação de emergência e vigor de plântulas. Crop Science, 2:176177 .

Marcos Filho J (2015) Seed vigor testing: an overview of the past, present and future perspective. Scientia Agricola, 72:363-374.

Marcos Filho J, Cicero SM \& Silva WR (1987) Avaliação da qualidade de sementes. Piracicaba, FEALQ. 320p.

Marques ER, Araújo RF, Araújo EF, Martins Filho S, Soares PC \& Mendonça EG (2014) Dormancy and enzymatic activity of rice cultivars seeds stored in different environments. Journal of Seed Science, 36:435-442.

Marques ER, Araújo EF, Araújo RF, Martins Filho S \& Soares PC (2014a) Seed quality of rice cultivars stored in different environments. Journal of Seed Science, 36:32-39.

Menezes NL, Pasqualli LL, Barbieri APP, Vidal MD \& Conceição GM (2012) Temperaturas de secagem na integridade física, qualidade fisiológica e composição química de sementes de arroz. Pesquisa Agropecuária Tropical, 42:430-436.

Morás A, Gelain J, Romano CM, Lorini I, Gularte MA \& Elias MC (2006) Effects of diatomaceous earth used to control stored grain pests on technological, physical and cooking characteristics of parboiled and conventionally processed rice. In: 9th International Working Conference on Stored Product Protection, Campinas. Anais, ABRAPOS. p. 816-822.

Park C, Kim Y, Park K \& Kim B (2018) Changes in physicochemical characteristics of rice during storage at different temperatures. Journal of Stored Products Research, 48:25-29.

Rodo AB, Panobianco M \& Marcos Filho J (2000) Metodologia alternativa do teste de envelhecimento acelerado para sementes de cenoura. Scientia Agricola, 57:289-292.

Saravia CT, Peres WB \& Risso J (2007) Manejo da temperatura do ar na secagem intermitente de sementes de arroz irrigado. Revista Brasileira de Sementes, 29:23-27.

Scariot MA, Radünz LL, Dionello RG, Toni JR, Mossi AJ \& Reichert Júnior FW (2018) Quality of wheat grains harvested with different moisture contentes and stored in hermetic and conventional system. Journal of Stored Products Research, 75:29-34.

Sosbai - Sociedade Sul-Brasileira de Arroz Irrigado (2016) Arroz irrigado: recomendações técnicas da pesquisa para o Sul do Brasil. Pelotas: Sosbai, 200p. 
Souza LCD, Yamashita OM \& Carvalho MAC (2007) Qualidade de sementes de arroz utilizadas no norte de Mato Grosso. Revista Brasileira de Sementes, 29:223-228.

Tiecker Junior A, Guimarães LE, Ferrari Filho E, Castro B, Del Ponte EM \& Dionello RG (2014) Qualidade Físico-Química de Sementes de Milho Armazenados com Diferentes Umidades em Ambientes Hermético e Não Hermético. Revista Brasileira de Milho e Sorgo, 13:174-186.

Vieira AR, Fraga AC, Vieira MGGC, Soares AA \& Oliveira JA (2002) Dormência e qualidade fisiológica de sementes de arroz armazenadas em diferentes regiões do estado de minas gerais. Ciência e Agrotecnologia, 26:33-44.
Vieira AR, Oliveira JÁ, Guimarães RM, Pinho ÉVRV, Pereira CE \& Clemente ACS (2008) Marcador isoenzimático de dormência em sementes de arroz. Revista Brasileira de Sementes, 30:8189

Wang P, Li D \& Wang L (2017) Drying damage on physiological properties of rice seed associated with ultrastructure changes. International Journal of Food Engineering, 13:1-9.

Ying G, Jianxin Y, Shenbin L, Huachang Z, Shuanglin W \& Lan L (1998) Effects of temperature on rice quality and mass loss. In: 7 th International Working Conference on Stored-Product Protection, Beijing. Anais, Sichuan Publishing House of Science and Technology. p.1413-1421 